\title{
2D-correlation analysis applied to in situ and operando
}

\section{Mössbauer spectroscopy}

\author{
Laurent Aldon ${ }^{*}{ }^{l}$, Alexis Perea ${ }^{l}$ \\ ${ }^{1}$ ICGM/AIME (UMR 5253 CNRS), CC 15-02, Université Montpellier II, \\ Place E. Bataillon, 34095 Montpellier Cedex 5, France
}

laurent.aldon@um2.fr

Friday, May 28, 2010

${ }^{1}$ Correspondence to: Laurent Aldon, IGCM- UMR 5253 CNRS, CC 15-02, Université Montpellier 2, 34095 Montpellier Cedex 5, France. E-mail: laurent.aldon@um2.fr 


\section{ABSTRACT}

In this paper we propose a new way for Mössbauer data treatment when numerous experimental spectra are recorded in operando conditions depending on a perturbation. In our exemple, the perturbation is the $\mathrm{Li}$ amount extracted from a positive electrode material $\mathrm{LiFe}_{0.75} \mathrm{Mn}_{0.25} \mathrm{PO}_{4}$. In other cases perturbation could be the recording temperature, the pressure or kinetic parameter or even time for isothermal experiments. From analysis of both synchronous and asynchronous $2 \mathrm{D}$ correlation spectra, we can focus our attention on the intensity variations at some specific positions deduced from crosspeaks. This analytical method is very powerful when overlap between absorption lines is observed. This is typically

the case when $\mathrm{Fe}^{2+} / \mathrm{Fe}^{3+}$ contributions are simultaneously present in a Mössbauer spectrum at lower velocities.

\section{Key words}

two-dimensional correlation spectroscopy, analytical method, Mössbauer spectrocopy, lithium battery, positive electrode materials, $\mathrm{LiFePO}_{4}, \mathrm{FePO}_{4}$, olivine, in situ and operando measurements, data treatment. 


\section{Introduction}

The electrochemical reactions of battery materials have been extensively studied by various electrochemical and spectroscopic techniques [1,2]. We recently determined Lamb-Mössbauer factors of both $\mathrm{FePO} 4$ and $\mathrm{LiFePO}_{4}$ compounds [3] in order to get precise contributions of each formed/reacted species during electrochemical process. Mössbauer is a powerful technique to follow electrochemical reactions studied by ex situ [4,5], in situ [6] or operando conditions and also for characterization of pristine materials. In some case it is possible to enriched electrode materials with a Mössbauer isotope $\left({ }^{57} \mathrm{Fe},{ }^{119} \mathrm{Sn}\right)$ used as a local probe in $\mathrm{Li}_{4} \mathrm{Ti}_{5} \mathrm{O}_{12}[7,8,9], \mathrm{Li}_{2} \mathrm{Ti}_{3} \mathrm{O}_{7}[10,11]$ for instance. In other cases spectra are broadened due to a mixture of phases or an amorphization of the particles. The help of electronic structure calculation $[18,19]$ allows non-trivial experimental attributions when mathematical ambiguities due to overlapping peaks was observed. Interpretation of both isomer shift and quadrupole splitting variations was explained with such theoretical approaches [20,21]. In the case of glassy compounds quadrupole splitting distributions have been used [22,23] based on previous works $[24,25,26]$.

Rechargeable lithium batteries have proven to be one of the most successful solutions to achieve good electrochemical performances in terms of cycleability, low cost, environmental benefit, easy to produce and safety in handling and operation. Phosphate materials $\left(\mathrm{Li}_{3} \mathrm{Fe}_{2}\left(\mathrm{PO}_{4}\right)_{3}\right.$ [27])have been investigated in the past for their good ionics properties as solid electrolytes. $\mathrm{The} \mathrm{LiFePO}_{4}$ compound has been chosen as cathode material because of the requirements[28,29]. Pure $\mathrm{LiFePO}_{4}$ (triphylite) and $\mathrm{FePO}_{4}$ (heterosite, berlinite [30, 31], high pressure [32] and amorphous [33] polymorphs) have been earlier studied for their electrochemical performances $[34,35,36]$ and their physico-chemical properties like antiferromagnetism [37] by X-ray [38,39] and neutron [40,41] diffraction techniques, Mössbauer spectroscopy $[42,43,44]$, Raman [45,46] and Infra-Red [47,48,49] spectroscopies, X-ray absorption [50] and X-ray photoelectron spectroscopies [51,52]. The origin of capacity loss during the first cycle was 
also discussed for this good candidate as cathode material [53]. Due to low ionic and electronic conductivity for $\mathrm{LiFePO}_{4}$, and to its ageing in presence of moisture[54,55], optimized particle size [56], mineral coating or substitutions $\left(\mathrm{LiFe}_{1-\mathrm{x}} \mathrm{Mn}_{\mathrm{x}} \mathrm{PO}_{4}[57,58,59,60]\right.$ or $\left.\mathrm{Li}_{1-\mathrm{x}} \mathrm{Fe}_{1+\mathrm{x}} \mathrm{P}_{1-\mathrm{x}} \mathrm{Si}_{\mathrm{x}} \mathrm{O}_{4}[61]\right)$, doping by transition metals [62], or carbon composites[63] have been proposed to overcome these issues.

In this paper we illustrate, taking advantage of $2 \mathrm{D}$-correlation spectroscopy analysis, a way to analyse Mössbauer spectra recorded in operando conditions. We have used Python[64] programming langage with Numpy[65] and Pylab[66] libraries to get 2D-correlation spectra. This concept of 2D-correlation was initially proposed by Noda $[67,68]$. In general 2D-correlation spectra are obtained using a perturbation (Temperature [69,70], $\mathrm{pH}$ [71], Lithium amount [72], kinetic data [73]) applied to the pristine material investigated by a given or several experimental spectroscopies. More details on this analytical method can be found here [74]. From our knowledge 2D-correlation spectroscopy analysis (2D-COSA) used for various experimental techniques (Infra-Red spectroscopy [75, 76], Mass spectral data [77], Resonance light scattering [78], X-ray photoelectron spectroscopy [79]) have not yet used for Mössbauer spectroscopy. We present here an application of 2D-COSA for ${ }^{57} \mathrm{Fe}$ in situ Mössbauer spectroscopy during electrochemical extraction of lithium from $\mathrm{LiFe}_{0.75} \mathrm{Mn}_{0.25} \mathrm{PO}_{4}$ with olivine structure.

\section{Theoretical basis}

\section{Generalized 2D Correlation Spectroscopy}

A set of $m$ experimental Mössbauer spectra are recorded as a function of a perturbation variable x (e.g., $\mathrm{Li}$ amount extracted/inserted during electrochemical tests) ranging from $\mathrm{x}_{\min }$ to $\mathrm{x}_{\max }$. The Li variation between two collected spectra is $\Delta \mathrm{x}=\left(\mathrm{x}_{\max }-\mathrm{x}_{\min }\right) /(\mathrm{m}-1)$. This continuous variation induces a broadening of the experimental spectra. Each raw spectrum is folded and normalized giving a set of $\mathrm{m}$ perturbationinduced dynamic spectra, $\quad$ is then transformed into a set of 2D correlation spectra by a form of 
spectrum given by :

Then we need the dynamic spectra obtained by :

The intensity of $2 D$ correlation spectrum $\mathrm{X}\left(\mathrm{v}_{1}, \mathrm{v}_{2}\right)$ reprensents the quantitative measure of a comparative similarity or dissimilarity of spectral intensity variations measured at two different velocities, $\mathrm{v}_{1}$ and $\mathrm{v}_{2}$, along with a fixed interval. In a Mössbauer spectrum $v_{i}$ corresponds to the position of a Lorentzian absorption line. In order to simplify numerical manipulation, $\mathrm{X}\left(\mathrm{v}_{1}, \mathrm{v}_{2}\right)$ is treated as a complex number :

comprising two orthogonal components, known respectively as the synchronous $\mathrm{S}\left(\mathrm{v}_{1}, \mathrm{v}_{2}\right)$ and the asynchronous $\mathrm{A}\left(\mathrm{v}_{1}, \mathrm{v}_{2}\right) 2 \mathrm{D}$ correlation intensities.

Using Python programming language, $\mathrm{S}\left(\mathrm{v}_{1}, \mathrm{v}_{2}\right)$ is calculated as follows :

$$
S=\operatorname{dot}\left(y \_d y n \cdot \operatorname{conj}() \cdot \operatorname{transpose}(), y \_d y n\right) / \text { float }(m-1)
$$

The intensity of the synchronous 2D correlation spectrum represents the simultaneous changes of two separate spectral intensity variations measured at $\mathrm{v}_{1}$ and $\mathrm{v}_{2}$ within the interval between $\mathrm{x}_{\min }$ and $\mathrm{x}_{\max }$. The autocorrelation spectrum $\mathrm{a}\left(\mathrm{v}_{\mathrm{i}}\right)$, defined by the diagonal of $\mathrm{S}$ matrix, presents peaks called autopeaks, whose magnitude is always positive. It represents the overall extent of spectral intensity variation at the specific velocity $\mathrm{v}_{\mathrm{i}}$ within the interval between $\mathrm{x}_{\min }$ and $\mathrm{x}_{\max }$. Crosspeaks located at the 
off-diagonal positions of a synchronous 2D spectrum represent simultaneous changes of spectral intensities observed at two differents velocities $v_{1}$ and $v_{2}$. Such a synchronized change suggests the possible existence of a coupled origin of the spectral intensity variations. The sign of synchronous crosspeak becomes positive if the spectral intensities of the two velocities corresponding to the coordinates of the crosspeak are either increasing or decreasing together within the observation interval. However, the negative sign of crosspeaks indicates that one of the spectral intensities in increasing while the other is decreasing.

The asynchronous $2 \mathrm{D}$ correlation spectrum $\mathrm{A}\left(\mathrm{v}_{1}, \mathrm{v}_{2}\right)$ is calculated in Python as follows:

$$
A=\operatorname{dot}\left(y \_d y n \cdot \operatorname{conj}() \cdot \operatorname{transpose}(), \operatorname{dot}(\mathrm{Njk}, \operatorname{spectres} d y n)\right) / \mathrm{float}(\mathrm{m}-1)
$$

In this previous expression $\mathrm{N}_{\mathrm{jk}}$ is the Hilbert-Noda matrix calculated as:

$$
\text { or } 0 \text { if } j=k
$$

The intensity of an asynchronous 2D correlation spectrum represents sequential, but not coincidental, changes of spectral intensities measured separately at $v_{1}$ and $v_{2}$. Crosspeaks develop only if the intensity varies out of phase with each other. The sign of asynchronous crosspeak provide useful information on sequential order of events observed by the Mössbauer spectroscopy along the lithium content. If the signs of synchronous and asynchronous crosspeaks are the same, the intensity change at $\mathrm{v}_{1}$ occurs before $\mathrm{v}_{2}$. If the signs of synchronous and asynchronous crosspeaks are different, the intensity change at $\mathrm{v}_{1}$ occurs after $\mathrm{v}_{2}$.

\section{Experimental}


$\mathrm{LiFe}_{0.75} \mathrm{Mn}_{0.25} \mathrm{PO}_{4}$ pristine compound was obtained by solid-state reaction. The precursors: $\mathrm{Li}_{2} \mathrm{CO}_{3}$ (Sigma-Aldrich, 99\%), $\mathrm{FeC}_{2} \mathrm{O}_{4} .2 \mathrm{H}_{2} \mathrm{O}$ (Labosi, 99.99\%), $\mathrm{Mn}^{\mathrm{II}}\left(\mathrm{CH}_{3} \mathrm{COO}\right)_{2}$ (Sigma-Aldrich, 98\%) and $\mathrm{NH}_{4} \mathrm{H}_{2} \mathrm{PO}_{4}$ (Acros Organics, 99.99\%) were first ball milled during $1 \mathrm{~h} 30$ and then thermally treated in a tube furnace under argon flow for 8 hours at $800^{\circ} \mathrm{C}$.

\section{$X$-ray diffraction pattern}

$\mathrm{LiFe}_{0.75} \mathrm{Mn}_{0.25} \mathrm{PO}_{4}$ pristine compound has been characterized by X-ray Power Diffraction with a Philips $\theta-2 \theta$ diffractometer using $\mathrm{CuK} \alpha$ radiation $(\lambda=1.5418 \AA)$ and a nickel filter.

Crystallographic reference data for $\mathrm{LiFePO}_{4}$ (triphylite) has been taken from Powder diffraction File (JCPDS \#81-1173, a=10.332 $\AA, \mathrm{b}=6.010 \AA, \mathrm{c}=4.692 \AA)$. These values and the orthorhombic Pnma space group have been used in the initial stages of refinement of the cell parameters for our $\mathrm{LiFe}_{0.75} \mathrm{Mn}_{0.25} \mathrm{PO}_{4}$ compound.

\section{${ }^{57}$ Fe Mössbauer measurements}

Mössbauer spectra have been recorded in the constant acceleration mode and in transmission geometry on a standard Mössbauer spectrometer composed of devices from Ortec and WissEl. A ${ }^{57} \mathrm{Co}(\mathrm{Rh})$ source with a nominal activity of $10 \mathrm{mCi}$ have been used. Each Mössbauer spectrum has been collected every 128 minutes with a deintercalation uptake $\Delta \mathrm{x}=0.053 \mathrm{Li}$ corresponding to an electrochemical rate of $\mathrm{C} / 40$ (1 Li extracted in 40 hours). The source has been always kept at RT. Calibration of the velocity scale was done using absorption lines of a $25 \mu \mathrm{m}$ iron foil. Isomer shifts are given relative to $\alpha$-Fe.

\section{Electrochemical measurements}


For Mössbauer measurements in operando conditions, we used a designed cell allowing to use it in a transmission configuration. The cell has been designed in such a way that gamma rays can go through the Be windows which are the current collector, the sample under study is in contact with an aluminum foil avoiding corrosion of the Be windows at high potential, and the lithium foil used as reference electrode. Olivine has been used as actived cathode material with carbon black (80:20) versus Li used as anode with a Whatman paper as separator using $1 M \mathrm{LiPF}_{6}$ in EC:PC:DMC. We used a rate of C/40, corresponding to $1 \mathrm{Li}$ extracted in $40 \mathrm{~h}$ with a potential window ranging from $3.2 \mathrm{~V}$ to $4.3 \mathrm{~V}$.

\section{Results and discussion}

For $\mathrm{LiFe}_{0.75} \mathrm{Mn}_{0.25} \mathrm{PO}_{4}$ sample, XRD measurements suggest pure phase within the detection limit of the apparatus as shown in figure 1. Our pristine material present XRD lines indexed in the Pnma space group with a set of cell parameters $a=10.356(6) \AA, b=6.025(4) \AA$ and $c=4.703(3) \AA$. Refined cell parameters have been obtained by pattern matching using FullProf program [80]. These values are in agreement with those published ealier [81].

In figure 2 we have represented the ${ }^{57} \mathrm{Fe}$ Mössbauer spectrum of the pristine material. The main contribution (91\%) with an isomer shift (IS) of $1.20(1) \mathrm{mm} / \mathrm{s}$ and a quadrupole splitting (QS) of 2.96(1)mm/s correspond to $\mathrm{Fe}^{2+}$ in the olivine structure. These values are in agreement with those found in the litterature[43]. Concerning the $\mathrm{Fe}^{3+}$ contribution detected in our Mössbauer spectra, the hyperfine parameters are IS $=0.31(4) \mathrm{mm} / \mathrm{s}$ and $\mathrm{QS}=0.85(8) \mathrm{mm} / \mathrm{s}$. These values are not very closed to those of $\mathrm{Li}_{\mathrm{X}} \mathrm{FePO}_{4}(\mathrm{OH})_{\mathrm{x}}$ (taverite)[55] the reaction product obtained from $\mathrm{LiFePO}_{4}$ ageing under moisture. The presence of such an impurity is not excluded since about $9 \%$ of $\mathrm{Fe}^{3+}$ is present and only $90 \%$ of the $\mathrm{Li}$ can be extracted by electrochemical reaction as can be seen in Figure 3. An other explanation of the $\mathrm{Fe}^{3+}$ contrubution may due to $\mathrm{Fe}_{2} \mathrm{O}_{3}$. From Mössbauer data recorded at various temperature, it has been shown that anisotropy constant can be determined[82]. Hence for $\alpha-\mathrm{Fe}_{2} \mathrm{O}_{3}{ }^{57} \mathrm{Fe}$ Mössbauer spectra present rather a doublet instead of a sextet at room temperature when particles are nanosized. This 
doublet presents hyperfine parameters ranging from IS $=0.32 \mathrm{~mm} / \mathrm{s} \quad Q S=0.98 \mathrm{~mm} / \mathrm{s} \quad(\mathrm{D}=4 \mathrm{~nm})$ to $\mathrm{IS}=0.38 \mathrm{~mm} / \mathrm{s}, \mathrm{QS}=0.44 \mathrm{~mm} / \mathrm{s}(\mathrm{D}=18 \mathrm{~nm})$ depending on the mean particle size. So, in our case, both IS and QS could be some $\mathrm{Fe}_{2} \mathrm{O}_{3}$ formed at high temperature. From linear correlation between QS and nanoparticle size we found a mean particle size of $\mathrm{D}=7 \pm 2 \mathrm{~nm}$ for our $\mathrm{Fe}_{2} \mathrm{O}_{3}$ impurity. Recently, Rho et al. have mentioned[83] the formation of both $\mathrm{Fe}_{2} \mathrm{P}$ (singlet+doublet) and $\mathrm{FeP}$ (IS=0.6(3)mm/s and $\mathrm{QS}=0.8(6) \mathrm{mm} / \mathrm{s})$ as impurity in $\mathrm{LiFePO}_{4}$.

The electrochemical curve shown in figure 3. presents two main regions. Starting for $[\mathrm{x}=1 \mathrm{Li}, \mathrm{V}=3.2 \mathrm{~V}]$ in $\mathrm{Li}_{\mathrm{x}} \mathrm{Fe}_{0.75} \mathrm{Mn}_{0.25} \mathrm{PO}_{4}$ we can extract about $\Delta \mathrm{x}=0.68 \mathrm{Li}$ (Mössbauer spectra\#1 to 13) on a mean voltage of about $3.48 \mathrm{~V}$. This voltage is known to be $\mathrm{Fe}^{2+} / \mathrm{Fe}^{3+}$ redox potential. Then from $[\mathrm{x}=0.32 \mathrm{Li}, \mathrm{V}=3.88 \mathrm{~V}]$ to $[\mathrm{x}=0.10, \mathrm{~V}=4.3 \mathrm{~V}]$ we observe a mean voltage at about $4.02 \mathrm{~V}$, corresponding to $\mathrm{Mn}^{2+} / \mathrm{Mn}^{3+}$ redox potential (Mössbauer spectra\#14 to 18). Assuming that $0.91 \mathrm{Li}$ have been used (9\% of nonelectrochemically active impurity observed in the Mössbauer spectrum, fig. 2), $\Delta x=0.68$ Li and $\Delta x=0.23$ $\mathrm{Li}$ are used to oxidize $\mathrm{Fe}^{2+}$ to $\mathrm{Fe}^{3+}$ and $\mathrm{Mn}^{2+}$ to $\mathrm{Mn}^{3+}$, respectively. These values are rather close to the expected one : $0.75 \times 0.91=0.683$ to oxidize $\mathrm{Fe}^{2+}$ and $0.25 \times 0.91=0.227$ to oxidize $\mathrm{Mn}^{2+}$, in a rather good agreement with the stoechiometric ratio Fe:Mn of 0.75:0.25.

We have represented in figure 4 the ${ }^{57} \mathrm{Fe}$ Mössbauer spectra obtained during electrochemical Li extraction as mentioned above. We clearly see the evolution of the absorption lines upon the perturbation, i.e. the $\mathrm{Li}$ content. In spectrum labeled 1, we retrieve the doublet of the olivine $\left(\mathrm{LiFe}^{2+}{ }_{0.75} \mathrm{Mn}^{2+}{ }_{0.25} \mathrm{PO}_{4}\right)$ constituted of the two peaks located at $\mathrm{v}_{1}=-0.28 \mathrm{~mm} / \mathrm{s}$ and $\mathrm{v}_{2}=2.68 \mathrm{~mm} / \mathrm{s}$, corresponding to the hyperfine parameters $\mathrm{IS}=1.2 \mathrm{~mm} / \mathrm{s}$ and $\mathrm{QS}=2.96 \mathrm{~mm} / \mathrm{s}$. After extraction of $\Delta \mathrm{x}=0.68$ $\mathrm{Li}$ (spectrum labeled 13), we observe the doublet of the lithiophilite $\left(\mathrm{Li}_{0.25} \mathrm{Fe}^{3+}{ }_{0.75} \mathrm{Mn}^{2+}{ }_{0.25} \mathrm{PO}_{4}\right)$ constituted of the two peaks located at $\mathrm{v}_{1}=-0.22 \mathrm{~mm} / \mathrm{s}$ and $\mathrm{v}_{2}=0.98 \mathrm{~mm} / \mathrm{s}$, corresponding to the hyperfine parameters $\mathrm{IS}=0.38 \mathrm{~mm} / \mathrm{s}$ and $\mathrm{QS}=1.20 \mathrm{~mm} / \mathrm{s}$. At the end of lithium extraction (spectrum labeled 18), we observe the doublet of the heterosite $\left(\mathrm{Fe}^{3+}{ }_{0.75} \mathrm{Mn}^{3+}{ }_{0.25} \mathrm{PO}_{4}\right)$ constituted of the two peaks located at $\mathrm{v}_{1}=-$ 
$0.36 \mathrm{~mm} / \mathrm{s}$ and $\mathrm{v}_{2}=1.18 \mathrm{~mm} / \mathrm{s}$, corresponding to the hyperfine parameters $\mathrm{IS}=0.41 \mathrm{~mm} / \mathrm{s}$ and $\mathrm{QS}=1.54 \mathrm{~mm} / \mathrm{s}$.

In figure 5 we have plotted the averaged spectrum wich give an indication of the regions affected by Li extraction. We see again three main peaks located at about $[-0.2,1.1$ and $2.6 \mathrm{~mm} / \mathrm{s}]$. This averaged spectrum is needed to calculate both 2D-correlation synchronous (Figure 6) and asynchronous (Figure 7) spectra.

In the 2D-correlation synchronous spectrum (figure 6), we see autopeaks with positive contribution (diagonal represented in figure 8) and crosspeaks with positive and negative intensities depending on the respective evolution of the intentities of two given velocities. Positive and negative crosspeaks have the following coordinates: ([a,f], $[\mathrm{d}, \mathrm{e}]$ and $[\mathrm{c}, \mathrm{g}])$ and $([\mathrm{a}, \mathrm{g}],[\mathrm{e}, \mathrm{g}]$ and $[\mathrm{f}, \mathrm{g}])$ respectively. In Table 1, we have reported the characteristic values of these coordinates.

The transmission intensity is slightly correlated due to the presence of small positive cross-peak with $[\mathrm{c}, \mathrm{g}]$ coordinates in the 2D-correlation synchronous spectrum. In figure 7 , cross-peak located at [c,g] presents a null intensity in the 2D-correlation asynchronous spectrum. In such analysis, positive (negative) values means that variation at a given velocity occurs before (after) the perturbation. In the context of Mössbauer spectroscopy, a close-to-zero value in the 2D-correlation asynchronous spectrum suggests that variation observed at 2 given velocities are coincidental. Hence, these two positions belongs to the same doublet of a specie defined by an isomer shift, IS $=\left(\mathrm{v}_{1}+\mathrm{v}_{2}\right) / 2$ and a quadrupole splitting, QS $=\mathrm{v}_{2}-\mathrm{v}_{1}$. Using this kind of analysis, we propose an attribution given in table 1. In table 2 , we have reported the hyperfine parameters deduced from the 2D-correlation analysis and those obtained from a classical fitting procedure. Our 2D-correlation becomes a new tool for analyses of rather complicated Mössbauer spectra presenting some overlaps between absorption lines and small variation from a spectrum to an other. Another point to emphasize is that 2D-correlation applied to Mössbauer spectroscopy allows to extract both isomer shift and quadrupole splitting of the species using the whole set of spectra instead of using data separately. 
The autocorrelation spectrum plotted in figure 8 shows the positions of these characteristic values. These sets of coordinates are used to represent the relative transmission variation upon Li content as shown in figure 9.

Relative transmission at velocity [g] continously increases from file \#1 to \#13 or \#14 and then still constant up to the end of the reaction (file\#18). This unambiguous position corresponds to the oxidation process of $\mathrm{Fe}^{2+}$ to $\mathrm{Fe}^{3+}$ in $\mathrm{Li}_{\mathrm{x}} \mathrm{Fe}_{0.75} \mathrm{Mn}_{0.25} \mathrm{PO}_{4}$. From $\mathrm{x}=1$ (file \#1) to $\mathrm{x}=0.34$ (between file \#13 and \#14), we can write the redox process as the following:

$$
\mathrm{LiFe}^{2+}{ }_{0.75} \mathrm{Mn}^{2+}{ }_{0.25} \mathrm{PO}_{4}-\mathrm{yLi} \rightarrow \mathrm{Li}_{1-\mathrm{y}} \mathrm{Fe}^{2+}{ }_{0.75-\mathrm{y}} \mathrm{Fe}^{3+}{ }_{\mathrm{y}} \mathrm{Mn}^{2+}{ }_{0.25} \mathrm{PO}_{4} . \quad(0<\mathrm{y}<0.75)
$$

Now, focussing our attention on relative transmission at velocities [d,e,f], we can have an idea of the mechanism involved during the next steps of the Li extraction. In fact, it corresponds in some way to what happens in the $\mathrm{Fe}^{3+}$ local environment. It is clear that any variation detected in the Mössbauer spectra may be due to oxidation of $\mathrm{Mn}^{2+}$ to $\mathrm{Mn}^{3+}$. Quadrupole splitting is known to be very sensitive to second neighbors effect, and to the charge of the ions. In figure 9 we can see that the relative transmission at [e] decreases from file\#1 to file\#13 and still constant until the end of the Li extraction. While the relative transmission at [d] decreases from file\#1 to file\#13 and then increases from file\#14 to file\#18. These observations suggest the following process:

$$
\mathrm{Li}_{0.25} \mathrm{Fe}^{3+}{ }_{0.75} \mathrm{Mn}^{2+}{ }_{0.25} \mathrm{PO}_{4}-(\mathrm{y}-0.75) \mathrm{Li} \rightarrow \mathrm{Li}_{1-\mathrm{y}} \mathrm{Fe}^{3+}{ }_{0.75} \mathrm{Mn}^{2+}{ }_{1-\mathrm{y}} \mathrm{Mn}^{3+}{ }_{\mathrm{y}-0.75} \mathrm{PO}_{4} \quad(0.75<\mathrm{y}<1)
$$

Hence, the presence of $\mathrm{Mn}^{3+}$ in the neighborhood of $\mathrm{Fe}^{3+}$ induces a higher quadrupole splitting due to the second neighbor shell. This can be related to change induced in the local symmetry of the $\mathrm{Fe}^{3+}$ site due the Jahn-Teller effect on $\mathrm{Mn}^{3+}\left(3 \mathrm{~d}^{4}\right)$. We also observed this by in situ XRD measurement (not the purpose of this paper) and our results are rather in a good agreement with those previously published by Yamada et al[63].

Concerning the Mössbauer investigations, we have shown by in situ and operando measurements that ${ }^{57} \mathrm{Fe}$ is directly sensitive to oxidation state of the iron $\left(\mathrm{Fe}^{2+} / \mathrm{Fe}^{3+}\right)$ during the first stage of the $\mathrm{Li}$ extraction as expected in figure 3. We have also shown that ${ }^{57} \mathrm{Fe}$ is indirectly sensitive the the second 
neighbor shell through variations of $\mathrm{Mn}$ oxidation state. The quadrupole splitting is ranging from $1.20 \mathrm{~mm} / \mathrm{s}$ when $\mathrm{Fe}^{3+}$ are surrounded by $\mathrm{Fe}^{3+}$ and $\mathrm{Mn}^{2+}$ sharing the $\mathrm{M} 2$ site of the olivine structure, to $1.54 \mathrm{~mm} / \mathrm{s}$ when $\mathrm{Fe}^{3+}$ are surrounded by $\mathrm{Fe}^{3+}$ and $\mathrm{Mn}^{3+}$.

\section{Conclusion}

2D-Correlation spectroscopy applied to Mössbauer spectroscopy during electrochemical studies of electrode materials in real conditions (in situ and operando) can be considered as a new tool for the Mössbauer community. This analytical technique gives valuable information on the electrochemical mechanisms involved in extraction (insertion) of lithium from (in) electrode materials. Compared to other spectroscopies, Mössbauer spectroscopy is a complementary technique since this electrode material is based on $\mathrm{Fe}^{2+} / \mathrm{Fe}^{3+}$ redox system, ${ }^{57} \mathrm{Fe}$ and gives valuable information at atomic scale in the bulk material, while XPS and Raman are more dedicated to surface analysis. With the help of 2D-correlation analysis, Mössbauer spectroscopy can be used in operando conditions, i.e. during Li insertion (extraction) in (from) electrode materials tested in real battery with the presence of current collector (Be windows), separator and Li foil. Hence Mössbauer effect measurements yield the evidence for the oxidation processes taking place in the course of lithium extraction.

2D-Correlation technique can be used in other interesting application like catalysis, in situ corrosion measurements, f-Lamb-Mössbauer factor determination for instance.

\section{Acknowledgements}

The authors would like to thank SAFT Company, Bordeaux and CNRS (contract SAFT/CNRS $\mathrm{N}^{\circ}$ 029888) for the financial support through the Ph.D. grant of Alexis Perea and the Région Languedoc Roussillon for the Mössbauer platform. 


\section{FIGURE CAPTIONS}

Figure 1. X-ray diffraction pattern of pristine $\mathrm{LiFe} 0.75 \mathrm{Mn} 0.25 \mathrm{PO}$. Cell parameters determined by LeBail method[80] using the Pnma space group are $\mathrm{a}=10.356(6) \AA, \mathrm{b}=6.025(4) \AA, \mathrm{c}=4.703(3) \AA$.

Figure 2. ${ }^{57 \mathrm{Fe}}$ Mössbauer spectrum recorded at room temperature. Experimental (open circle) and calculculated spectrum (solid line) are represented. A small contribution (in red) due to Fe3+ impurity (see text for explanation) is also shown for clarity.

Figure 3. Electrochemical curve recorded during lithium extraction from $\mathrm{LiFe} 0.75 \mathrm{Mn} 0.25 \mathrm{PO}$. The numbered labels correspond to the file number of the recorded ${ }^{57 \mathrm{Fe}}$ Mössbauer spectra in operando conditions.

Figure 4. ${ }^{57 \mathrm{Fe}}$ Mössbauer spectra recorded in operando conditions during Li extraction from pristine $\mathrm{LiFe} 0.75 \mathrm{Mn} 0.25 \mathrm{PO}$. Labels 1 and 18 correspond to $\mathrm{LiFe} 0.75 \mathrm{Mn} 0.25 \mathrm{PO} 4$ and $\mathrm{Fe} 0.75 \mathrm{Mn} 0.25 \mathrm{PO} 4$ respectively. Colored lines [a-g] correspond to cross-correlation peaks positions observed in the synchronous spectra. The evolution of the intensity for those specific positions are discussed in the text.

Figure 5. Averaged spectrum determined from the mean of the 18 Mössbauer spectra recorded during extraction of Li. The main absorption peak located at negative velocity is due to the overlap between contributions of both $\mathrm{Fe} 2+$ and $\mathrm{Fe} 3+$. The peak located near $1 \mathrm{~mm} / \mathrm{s}$ correspond to $\mathrm{Fe} 3+$ contribution and the peak at $2.6 \mathrm{~mm} / \mathrm{s}$ correspond to $\mathrm{Fe} 2+$ contribution.

Figure 6. 2D-correlation synchronous spectrum obtained from experimental ${ }^{57 \mathrm{Fe}}$ spectra recorded during electrochemical lithium extraction from $\mathrm{LiFe} 0.75 \mathrm{Mn} 0.25 \mathrm{PO}$. Positive (light green) and negative (dark green) crosspeaks are observed. Positive crosspeaks have the following coordinates : $[\mathrm{a}, \mathrm{f}],[\mathrm{d}, \mathrm{e}]$ and $[\mathrm{c}, \mathrm{g}]$, while negative crosspeaks have mainly the following coordinates: $[\mathrm{a}, \mathrm{g}],[\mathrm{e}, \mathrm{g}]$ and $[\mathrm{f}, \mathrm{g}]$.

Figure 7. 2D-correlation asynchronous spectrum obtained from experimental ${ }^{57 \mathrm{Fe}}$ spectra recorded during electrochemical lithium extraction from $\mathrm{LiFe} 0.75 \mathrm{Mn} 0.25 \mathrm{PO}$. Positive crosspeaks (light green) negative crosspeaks (dark green) suggest variation at a given velocity occurs before (after) for an other velocity.

Figure 8. Autocorrelation spectrum determined from the 2D-correlation synchronous spectrum. Features previously observed in both synchronous and asynchronous correspond to either close to maxima in the autocorrelation spectrum [a, d, e, f] or minimum [c]. This latter peak is more broadened than those centered at about $2.7 \mathrm{~mm} / \mathrm{s}$. It contains some meaningful information as can be read in the text.

Figure 9. Evolution of the relative transmission for various velocities [a-g] vs. file number. A decrease in the relative transmission correspond to an increase of absorption at a given velocity. 


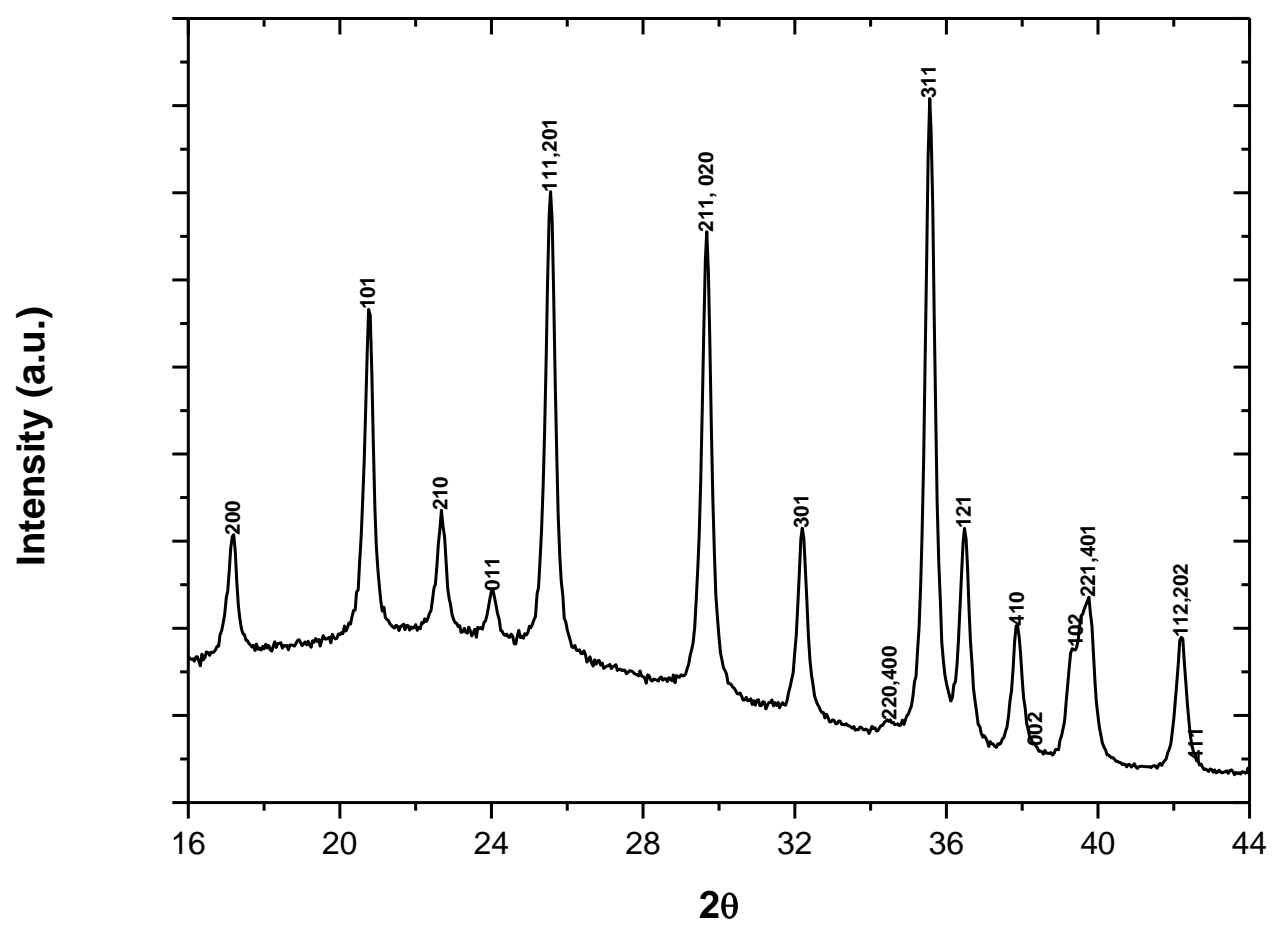

Figure 1. X-ray diffraction pattern of pristine $\mathrm{LiFe}_{0.75} \mathrm{Mn}_{0.25} \mathrm{PO}_{4}$. Cell parameters determined by LeBail method[80] using the Pnma space group are $a=10.356(6) \AA, b=6.025(4) \AA, c=4.703(3) \AA$. . 




Figure 2. ${ }^{57} \mathrm{Fe}$ Mössbauer spectrum recorded at room temperature. Experimental (open circle) and calculculated spectrum (solid line) are represented. A small contribution (in red) due to $\mathrm{Fe}^{3+}$ impurity (see text for explanation) is also shown for clarity. 


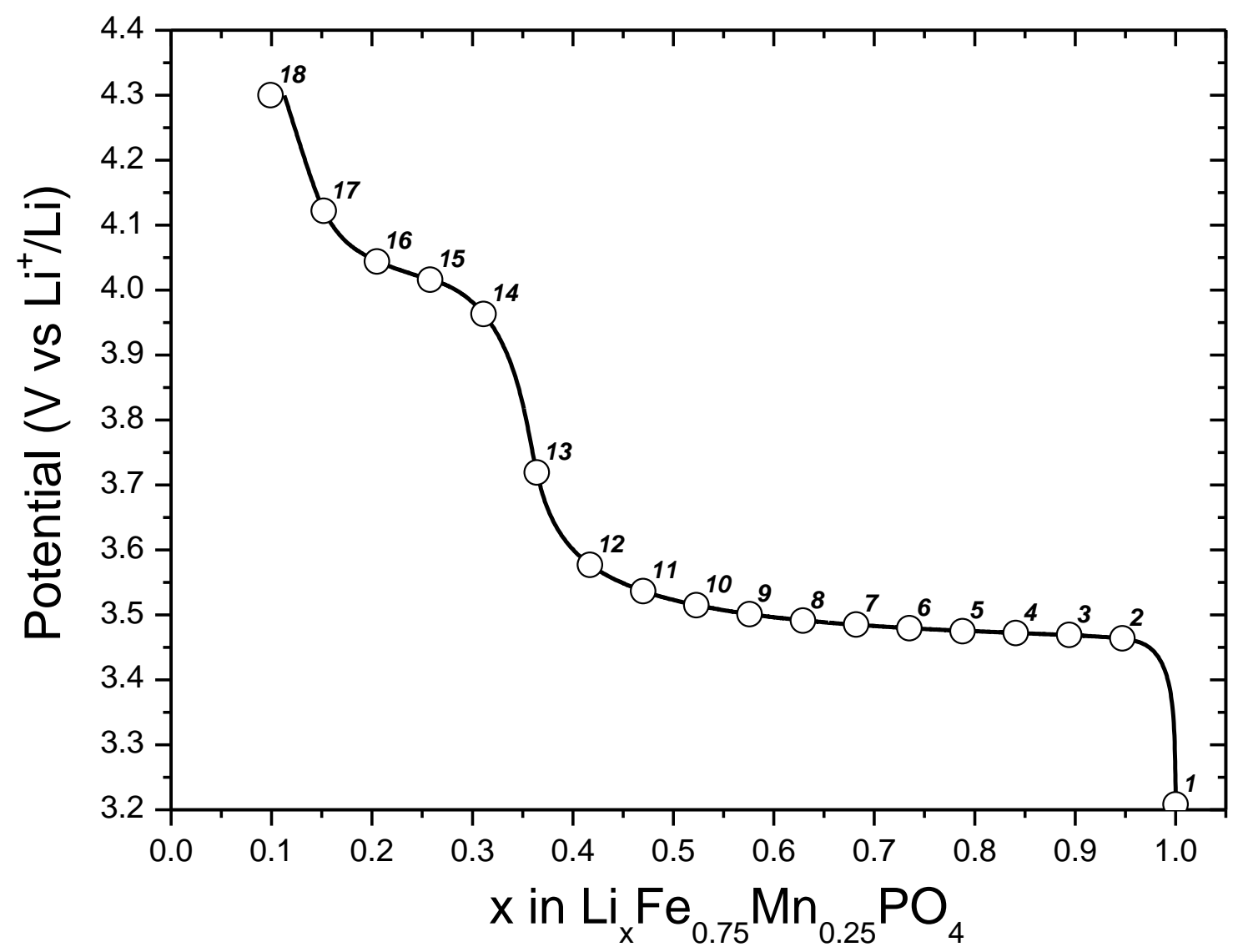

Figure 3. Electrochemical curve recorded during lithium extraction from $\mathrm{LiFe}_{0.75} \mathrm{Mn}_{0.25} \mathrm{PO}_{4}$. The numbered labels correspond to the file number of the recorded ${ }^{57} \mathrm{Fe}$ Mössbauer spectra in operando conditions. 


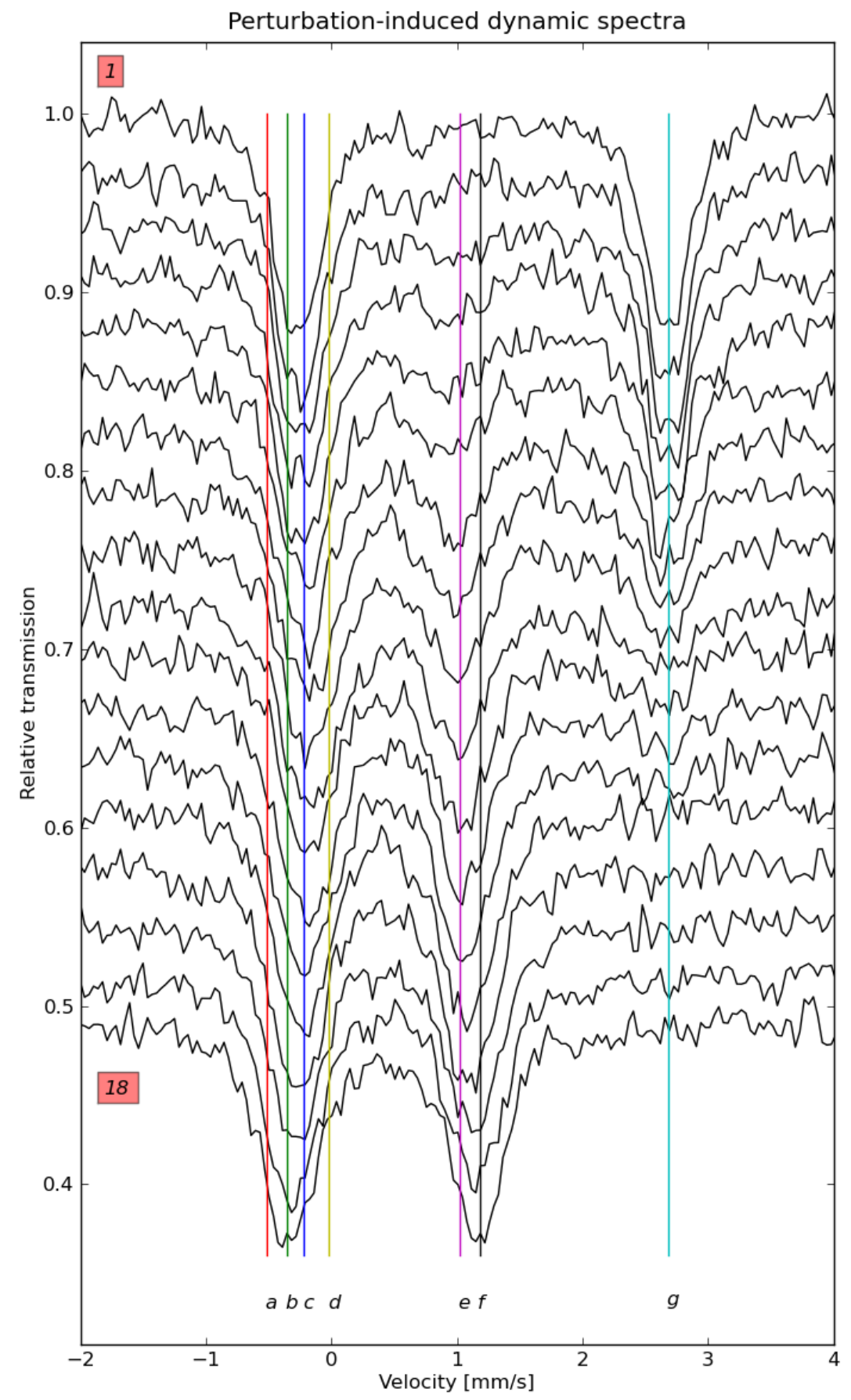

Figure 4. ${ }^{57} \mathrm{Fe}$ Mössbauer spectra recorded in operando conditions during Li extraction from pristine $\mathrm{LiFe}_{0.75} \mathrm{Mn}_{0.25} \mathrm{PO}_{4}$. Labels 1 and 18 correspond to $\mathrm{LiFe}{ }_{0.75} \mathrm{Mn}_{0.25} \mathrm{PO}_{4}$ and $\mathrm{Fe}_{0.75} \mathrm{Mn}_{0.25} \mathrm{PO}_{4}$ respectively. Colored lines [a-g] correspond to cross-correlation peaks positions observed in the synchronous spectra. The evolution of the intensity for those specific positions are discussed in the text. 


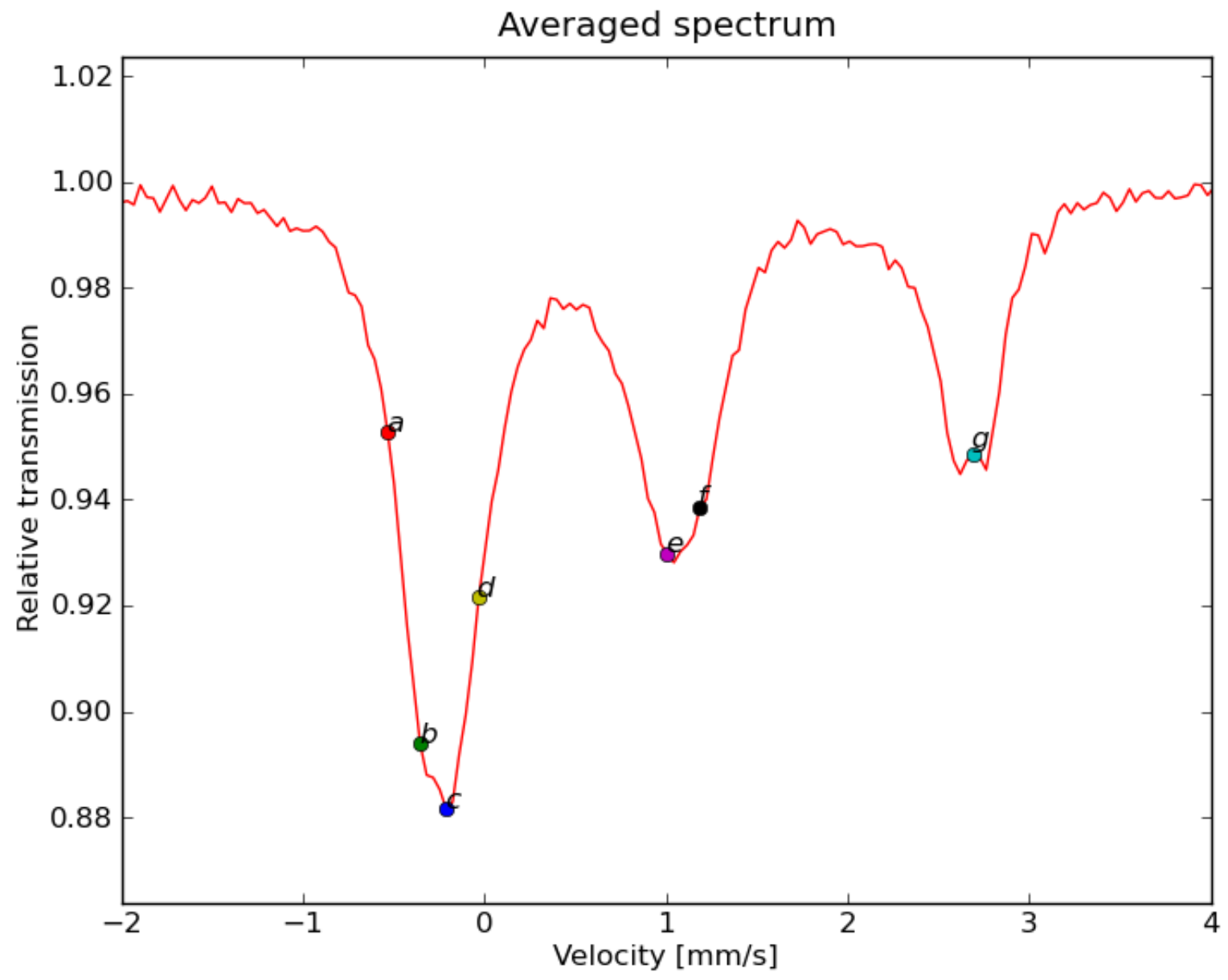

Figure 5. Averaged spectrum determined from the mean of the 18 Mössbauer spectra recorded during extraction of Li. The main absorption peak located at negative velocity is due to the overlap between contributions of both $\mathrm{Fe}^{2+}$ and $\mathrm{Fe}^{3+}$. The peak located near $1 \mathrm{~mm} / \mathrm{s}$ correspond to $\mathrm{Fe}^{3+}$ contribution and the peak at $2.6 \mathrm{~mm} / \mathrm{s}$ correspond to $\mathrm{Fe}^{2+}$ contribution. 


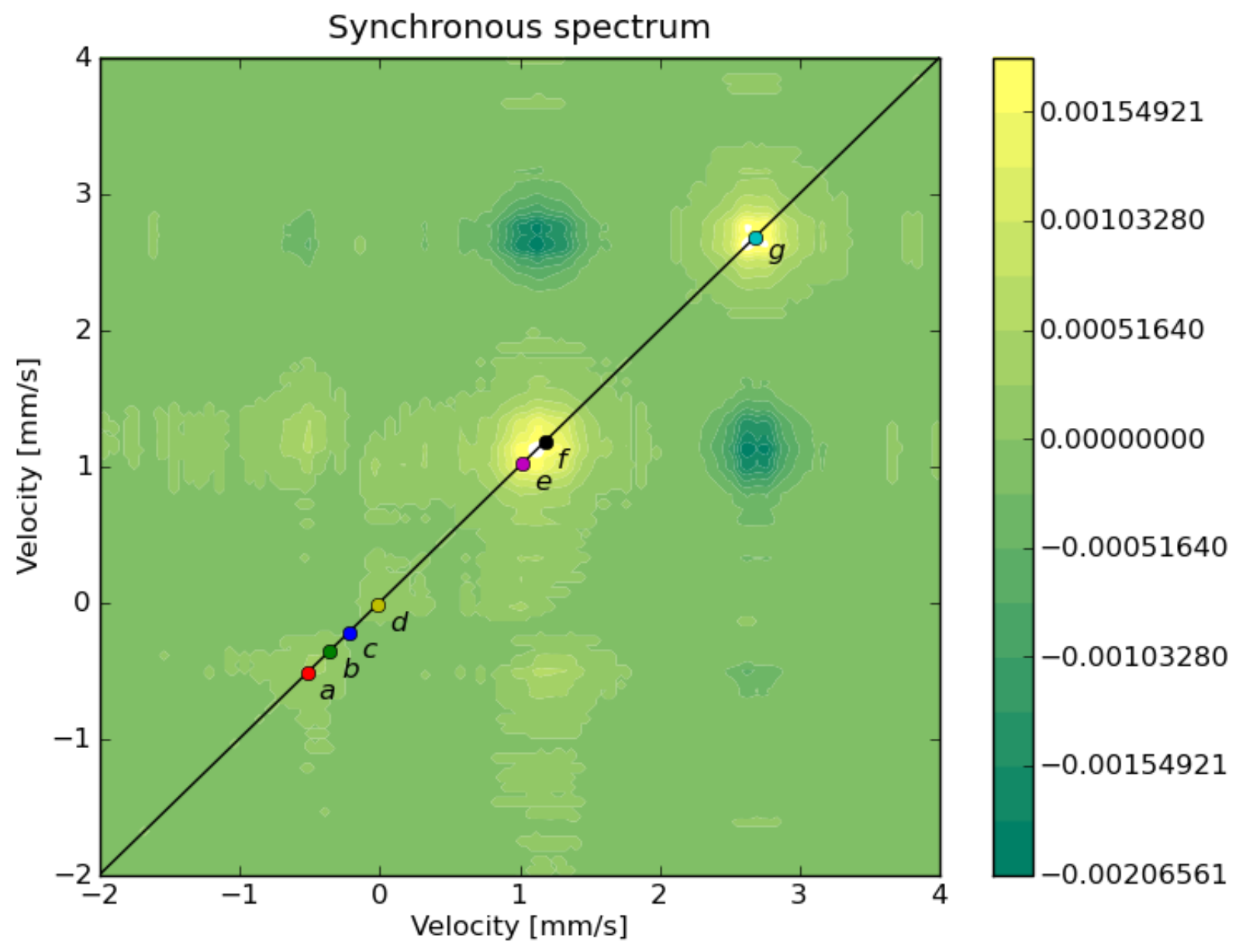

Figure 6. $2 \mathrm{D}$-correlation synchronous spectrum obtained from experimental ${ }^{57} \mathrm{Fe}$ spectra recorded during electrochemical lithium extraction from $\mathrm{LiFe}_{0.75} \mathrm{Mn}_{0.25} \mathrm{PO}_{4}$. Positive (light green) and negative (dark green) crosspeaks are observed. Positive crosspeaks have the following coordinates : [a,f], [d,e] and $[\mathrm{c}, \mathrm{g}]$, while negative crosspeaks have mainly the following coordinates: $[\mathrm{a}, \mathrm{g}],[\mathrm{e}, \mathrm{g}]$ and $[\mathrm{f}, \mathrm{g}]$. 


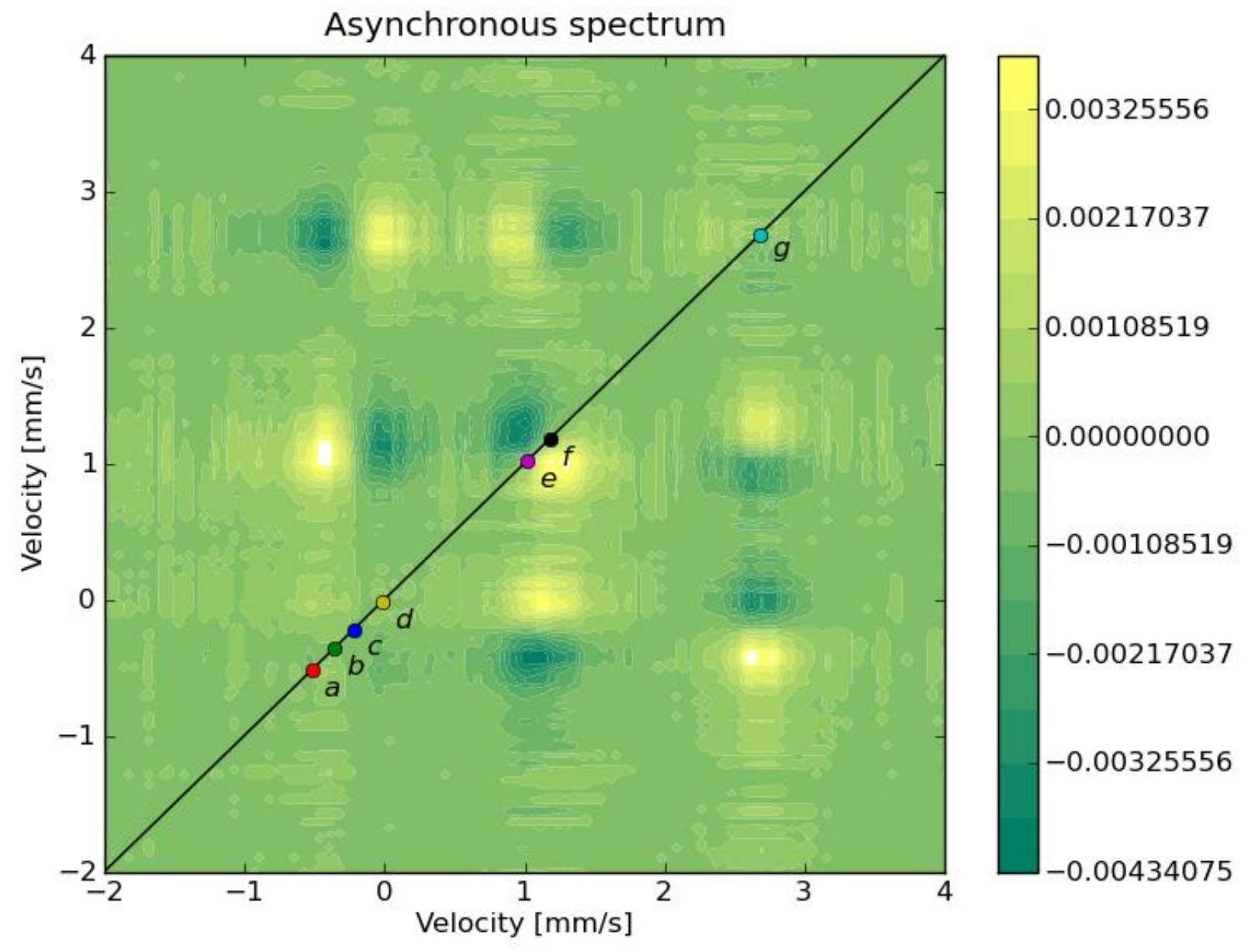

Figure 7. 2D-correlation asynchronous spectrum obtained from experimental ${ }^{57} \mathrm{Fe}$ spectra recorded during electrochemical lithium extraction from $\mathrm{LiFe}_{0.75} \mathrm{Mn}_{0.25} \mathrm{PO}_{4}$. Positive crosspeaks (light green) negative crosspeaks (dark green) suggest variation at a given velocity occurs before (after) for an other velocity. In the context of Mössbauer spectroscopy, a close-to-zero value in the asynchronous spectrum means and a positive value in the synchronous of a cross-peak like $[\mathrm{c}, \mathrm{g}]$ suggest that the to velocities belong to the same specie defined by an isomer shift $(\mathrm{c}+\mathrm{g}) / 2$ and a quadrupole splitting (g-c). 


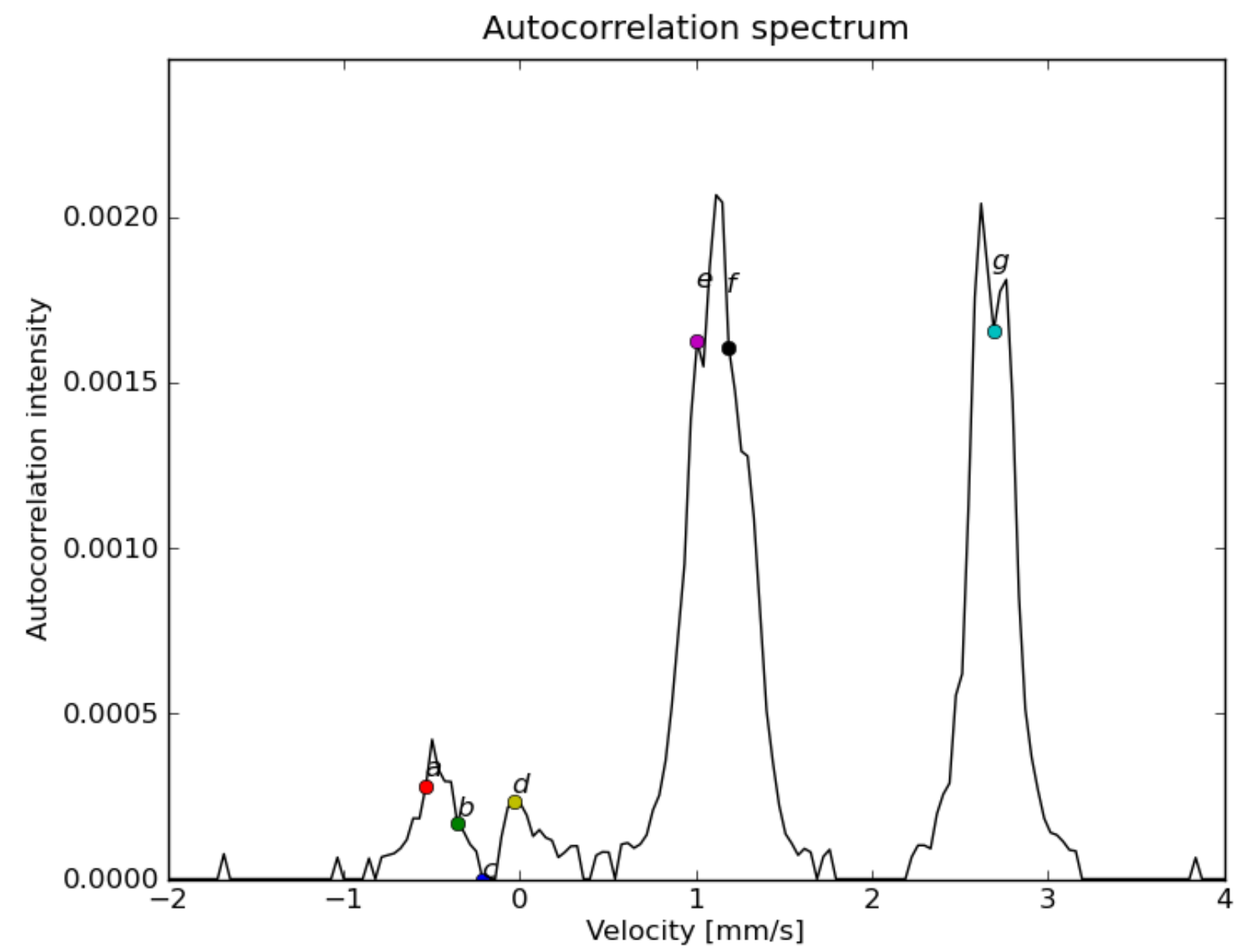

Figure 8. Autocorrelation spectrum determined from the 2D-correlation synchronous spectrum. Features previously observed in both synchronous and asynchronous correspond to either close to maxima in the autocorrelation spectrum $[\mathrm{a}, \mathrm{d}, \mathrm{e}, \mathrm{f}]$ or minimum $[\mathrm{c}]$. This latter peak is more broadened than those centered at about $2.7 \mathrm{~mm} / \mathrm{s}$. It contains some meaningful information as can be read in the text. 


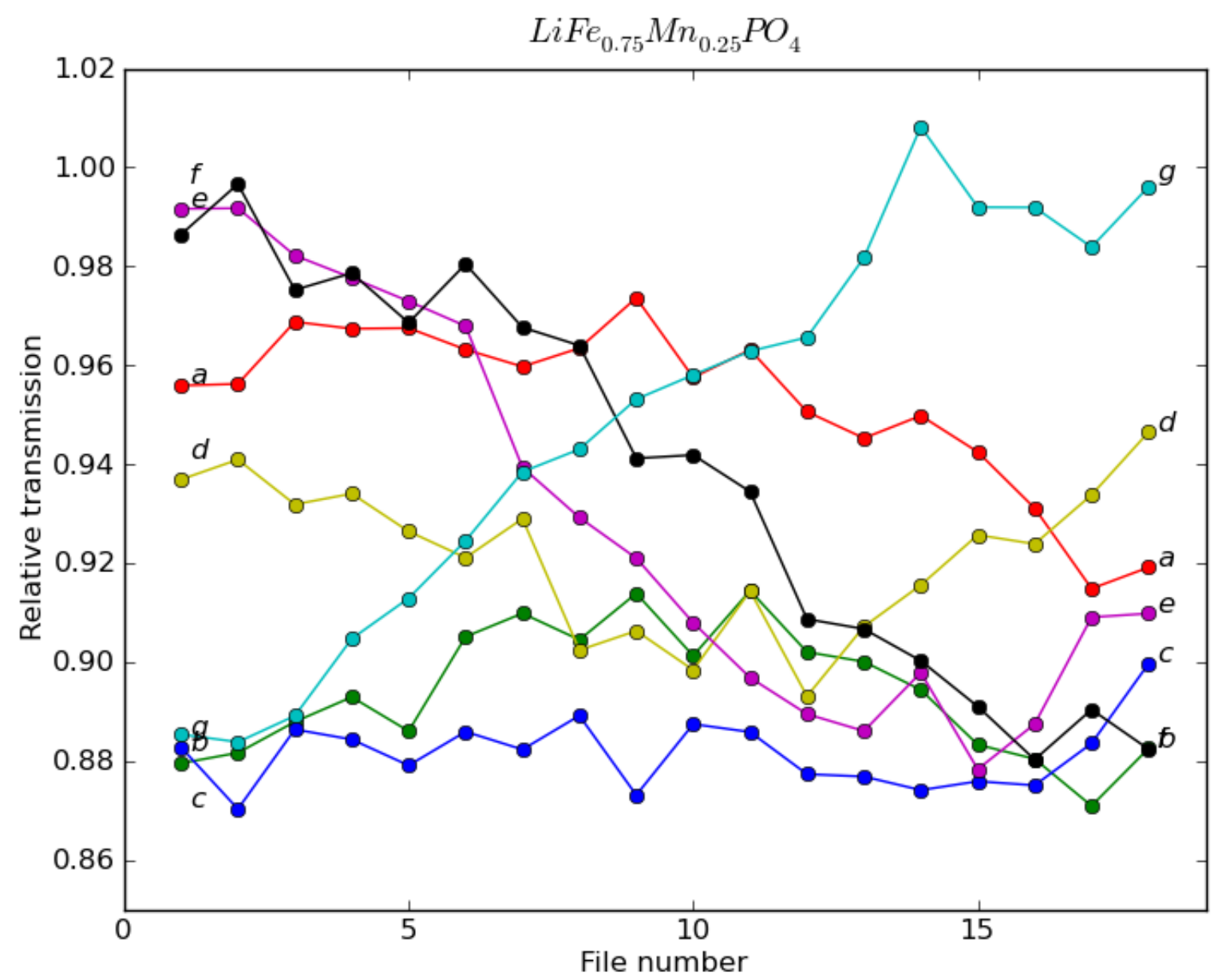

Figure 9. Evolution of the relative transmission for various velocities [a-g] vs. file number. A decrease in the relative transmission correspond to an increase of absorption at a given velocity. 
TABLES.

Table 1. Velocities of the main features [a-g] deduced from crosspeaks analysis of both 2D-correlation synchronous and asynchronous spectra and autocorrelation spectrum. Some attributions are given as an help for the discussion.

\begin{tabular}{|l|l|l|l|l|l|l|l|}
\hline Features & a & b & c & d & e & f & g \\
\hline $\begin{array}{l}\text { Velocity } \\
(\mathrm{mm} / \mathrm{s})\end{array}$ & -0.52 & -0.36 & -0.22 & -0.02 & 1.02 & 1.18 & 2.68 \\
\hline Attribution & & $\mathrm{v}_{1}\left(\mathrm{Fe}^{\mathrm{III}}{ }_{2}\right)$ & $\mathrm{v}_{1}\left(\mathrm{Fe}^{\mathrm{II}}\right)$ & $\mathrm{v}_{1}\left(\mathrm{Fe}^{\mathrm{III}}{ }_{1}\right)$ & $\mathrm{v}_{2}\left(\mathrm{Fe}^{\mathrm{III}}{ }_{1}\right)$ & $\mathrm{v}_{2}\left(\mathrm{Fe}^{\mathrm{III}}{ }_{2}\right)$ & $\mathrm{v}_{2}\left(\mathrm{Fe}^{\mathrm{II}}\right)$ \\
\hline
\end{tabular}

Table 2. Comparison of isomer shift and quadrupole splitting ( $\delta_{\text {calc }}$ and $\Delta_{\text {calc }}$ in $\mathrm{mm} / \mathrm{s}$ ) deduced from 2Dcorrelation analysis and those obtained by least-square fitting procedure $\left(\delta_{\mathrm{fit}}\right.$ and $\Delta_{\mathrm{fit}}$ in $\left.\mathrm{mm} / \mathrm{s}\right)$.

\begin{tabular}{|c|c|c|c|c|c|c|}
\hline & $\mathrm{v}_{1}$ & $\mathrm{v}_{2}$ & $\delta_{\text {calc }}$ & $\Delta_{\text {calc }}$ & $\delta_{\text {fit }}$ & $\Delta_{\text {fit }}$ \\
\hline $\mathrm{Fe}^{\mathrm{II}}$ & $-0.22(\mathrm{c})$ & $2.68(\mathrm{~g})$ & 1.23 & 2.90 & 1.20 & 2.96 \\
\hline $\mathrm{Fe}^{\mathrm{III}}{ }_{1}$ & $-0.02(\mathrm{~d})$ & $1.02(\mathrm{e})$ & 0.52 & 1.04 & 0.38 & 1.20 \\
\hline $\mathrm{Fe}^{\mathrm{III}}{ }_{2}$ & $-0.36(\mathrm{a})$ & $1.18(\mathrm{f})$ & 0.41 & 1.54 & 0.41 & 1.54 \\
\hline
\end{tabular}




\section{References}

[1] L. Aldon, C.M. Ionica, P.E. Lippens, D. Larcher, J.M. Tarascon, J. Olivier-Fourcade, J.-C. Jumas, Hyperfine Interactions, 167 (2006) 729.

[2] A. Aboulaich, F. Robert, P.E. Lippens, L. Aldon, J. Olivier-Fourcade, P. Willmann, J.-C. Jumas, Hyperfine Interactions, 167 (2006) 733.

[3] L. Aldon, A. Perea, M. Womes, C.M. Ionica-Bousquet, J.-C. Jumas, J. Solid State Chem., 183 (2010) 218.

[4] M. Mouyane, L. Aldon, M. Womes, B. Ducourant, J.-C. Jumas, J. Olivier-Fourcade, J. Power Sources, 189 (2009) 818.

[5] A. Ibarra-Palos, C. Darie, O. Proux, J. L. Hazemann, L. Aldon, J.-C. Jumas, M. Morcrette, P. Strobel, Chem. Mater., 14 (2002) 1166.

[6] C.M. Ionica-Bousquet, P.E. Lippens, L. Aldon, J. Olivier-Fourcade, J.-C. Jumas, Chem. Mater., 18 (2006) 6442.

[7] L. Aldon, P. Kubiak, M. Womes, J. C. Jumas, J. Olivier-Fourcade, J.L. Tirado, J.I. Corredor, C. Perez Vicente, Chem. Mater., 16 (2004) 5721.

[8] L. Aldon, P. Kubiak, A. Picard, P.E. Lippens, J. Olivier-Fourcade, J.-C. Jumas, Hyperfine Interactions, 156/157 (2004) 497.

[9] P. Kubiak, A. Garcia, M. Womes, L. Aldon, J. Olivier-Fourcade, P.E. Lippens, J.-C. Jumas, J. Power Sources, 119 (2003) 626.

[10] M. Van Thournout, L. Aldon, M. Womes, B. Ducourant, J. Olivier-Fourcade, C. Tessier, S. Levasseur, J. Power Sources, 174 (2007) 1270.

[11] L. Aldon, M. Van Thournout, P. Strobel, O. Isnard, J. Olivier-Fourcade, J.-C. Jumas, Solid State Ionics, 177 (2006) 1185 .

[18] P.E. Lippens, L. Aldon, C.M. Ionica, F. Robert, J. Olivier-Fourcade, J.-C. Jumas, Solid State Ionics, 835 (2005) 249.

[19] P.E. Lippens, J.-C. Jumas, J. Olivier-Fourcade, L. Aldon, A. Gheorghiu-de la Roque, C.Sénémaud, J. Phys. Chem. Solids, 61 (2000) 1761.

[20] M.L. Elidrissi Moubtassim, L. Aldon, P.E. Lippens, J. Olivier-Fourcade, J.-C. Jumas, G.Zegbe, G. Langouche, J. Alloys Compounds 228 (1995) 137.

[21] P.E. Lippens, L. Aldon, J. Olivier-Fourcade, J.-C. Jumas, A. Gheorghiu-de la Roque, C. Sénémaud, J. Phys. Chem. Solids, 60 (1999) 1745.

[22] F. Robert, F. Morato, J. Chouvin, L. Aldon, P.E. Lippens, J. Olivier-Fourcade, J.-C. Jumas, B. Simon, Ph. Biensan, J. Power Sources, 119 (2003) 581.

[23] L. Aldon, P.E. Lippens, J.-C. Jumas, J. Olivier-Fourcade, H. Bemelmans, G. Langouche, J. Non-Cryst. Solids, 262 (2000) 244.

[24] G. Le Caër, J.M. Dubois, J. Phys., E12 (1979) 1083. 
[25] H.V. Alberto, J.L. Pinto de Cunha, B.O. Mysen, J.M. Gil, N. Ayres de Campos, J. Non-Cryst. Solids, 194 (1996) 48.

[26] J. Y. Ping, D. G. Rancourt, Z. M. Stadnik, Hyperfine Interactions, 69 (1992) 493.

[27] A.S. Andersson, B. Kalska, P. Eyob, D. Aernout, L. Häggström, J.O. Thomas, Solid State Ionics, 140 (2001) 63.

[28] A.K. Padhi, K.S. Nanjundaswamy, J.B. Goodenough, J. Electrochem. Soc., 144 (1997) 1188.

[29] B.L. Ellis, K.T. Lee, L.F. Nazar, Chem. Mater., 22 (2010) 691.

[30] N. Kinomura, M. Shimada, M. Koizumi, S. Kume, Mater. Res. Bull., 11 (1976) 457.

[31] M.P. Pasternak, G. Kh. Rozenberg, A.P. Milner, M. Amanovicz, T. Zhou, U. Schwarz, K. Syassen, R.D. Taylor, M. Hanfland, K. Brister, Phys. Rev., B79 (1997) 4409.

[32] M.E. Arroyo-de Dompablo, J.M. Gallardo-Amores, M.T. Azcondo, F. Garcia-Alvarado, U. Amador, J. Phys. Chem. Solids, 67 (2006) 1243.

[33] S. Okada, T. Yamamoto, Y. Okazaki, J.-I. Yamaki, M. Tokunaga, T. Nishida, J. Power Sources, 146 (2005) 570.

[34] T. Shiratushi, S. Okada, J.-I. Yamaki, S. Yamashita, T. Nishida, J. Power Sources, 173 (2007) 979.

[35] K. Zaghib, N. Ravet, M. Gauthier, F. Gendron, A. Mauger, J.B. Goodenough, C.M. Julien, J. Power Sources, 163 (2006) 560 .

[36] C. Delmas, M. Maccario, L. Croguennec, F. Le Cras, F. Weill, Nature Mater., 7 (2008) 665.

[37] R.P. Santoro, R.E. Newnham, Acta Cryst., 22 (1967) 344.

[38] V. A. Streltsov, E.L. Belokoneva, V.G. Tsirelson, N.K. Hansen, Acta Cryst., B49 (1993) 147.

[39] H.C. Shin, K.Y. Chung, W.S. Min, D.J. Byun, H. Jang, B.W. Cho, Electrochem. Commun., 10 (2008) 536.

[40] G. Rousse, J. Rodriguez-Carvajal, S. Patoux, C. Masquelier, Chem. Mater., 15 (2003) 4082.

[41] C. Delacourt, J. Rodriguez-Carvajal, B. Schmitt, J.M. Tarascon, C. Masquelier, Solid State Sciences, 7 (2005) 1506.

[42] M.P. Pasternak, G. Kh. Rozenberg, A.P. Milner, M. Amanovicz, K.E. Brister, R.D. Taylor, J. Magnetism Magn. Mater., 183 (1998) 185.

[43] A.S. Andersson, B. Kalska, L. Häggström, J.O. Thomas, Solid State Ionics, 130 (2000) 41.

[44] K. Hirose, T. Honma, Y. Doi, Y. Hinatsu, T. Komatsu, Solid State Commun., 146 (2008) 273.

[45] R. Baddour-Hadjean; J.P. Pereira-Ramos, Chem. Rev., 110 (2010) 1278.

[46] C.V. Ramana, A. Mauger, F. Gendron, C.M. Julien, K. Zaghib, J. Power Sources, 187 (2009) 555.

[47] P. Jozwiak, J. Garbarczyk, F. Gendron, A. Mauger, C.M. Julien, J. Non-Cryst. Solids, 354 (2008) 1915.

[48] S. Hamelet, P. Gibot, M. Casas-Cabanas, D. Bonnin, C.P. Grey, J. Cabana, J.-B. Leriche, J. Rodriguez-Carvajal, M. Courty, S. Levasseur, P. Carlach, M. Van Thournout, J.M. Tarascon, C. Masquelier, J. Mater. Chem., 19 (2009) 3979.

[49] C.M. Burba, R. Frech, Electrochemica Acta, 52 (2006) 780. 
[50] A.A.M. Prince, S. Mylswamy, T.S. Chan, R.S. Liu, B. Hannoyer, M. Jean, C.H. Shen, S.M. Huang, J.F. Lee, G.X. Wang, Solid State Communications, 132 (2004) 455.

[51] R. Dedryvère, M. Maccario, L. Croguennec, F. Le Cras, C. Delmas, D. Gonbeau, Chem. Mater., 20 (2008) 7164.

[52] L .El Ouatani, R. Dedryvère, C. Siret, Ph. Biensan, D. Gonbeau, J. Electrochem. Soc., 156 (2009) 468.

[53] A.S. Andersson, J.O. Thomas, J. Power Sources, $97-98$ (2001) 498.

[54] K. Zaghib, M. Dontigny, P. Charest, J.F. Labrecque, A. Guerfi, M. Kopec, A. Mauger, F. Gendron, C.M. Julien, J.Power Sources, 185 (2008) 698.

[55] M. Cuisinier, J.-F. Martin, N. Dupré, A. Yamada, R. Kanno, D. Guyomard, Electrochem. Commun., 12 (2010) 238.

[56] A. Yamada, S.C. Chung, K. Hinokuma, J. Electrochem. Soc., 148 (2001) A224.

[57] C. Delacourt, C. Wurm, P. Reale, M. Morcrette, C. Masquelier, Solid State Ionics, 173 (2004) 113.

[58] C.M. Burba, R. Frech, J. Power Sources, 172 (2007) 870.

[59] J. Molenda, W. Ojczyk, K. Swierczek, W. Zajac, F. Frok, J. Dygas, Ru-Shi Liu, Solid State Ionics, 177 (2006) 2617.

[60] J.M. Osorio-Guillen, B. Holm, R. Ahuja, B. Johansson, Solid State Ionics, 167 (2004) 221.

[61] N. Recham, M. Casas-Cabanas, J. Cabana, C.P. Grey, J.-C. Jumas, L. Dupont, M. Armand, J.M. Tarascon, Chem. Mater., 20 (2008) 6798.

[62] D.X. Gouveia, V. Lemos, J.A.C. de Paiva, A.G. Souza Filho, J. Mendes Filho, S.M. Lala, L.A. Montoro, J.M. Rosolen, Phys. Rev., B72 (2005) 24105

[63] A. Yamada, M. Hosoya, S.-C. Chung, Y. Kudo, K. Hinokuma, K.-Y. Liu, Y. Nishi, J. Power Sources, 119-121 (2003) 232.

[64] Python (Release 2.6.4 for win32) free download at http://www.python.org

[65] Numerical Python (Release 1.4.0.dev7335), an Open Source Project developed by D. Ascher, P. F. Dubois, K. Hinsen, J. Hugunin, T. Oliphant.

[66] Pylab and Matplotlib (Release 0.99.1), a Graphic Library developed by D. Dale, M. Droettboom, E. Firing, J. Hunter.

[67] I. Noda, J. Molecular Structure, 883-884 (2008) 216.

[68] I. Noda, Appl. Spectrosc., 47 (1993) 1329.

[69] S. Morita, K. Kitagawa, I. Noda, Y. Ozaki, J. Molecular Structure, 883-884 (2008) 181.

[70] H. Ji, S.B. Kim, I. Noda, Y.M. Jung, Spectrochimica Acta, A71 (2009) 1873.

[71] X. Dou, B. Yuan, H. Zhao, G. Yin, O. Yukihiro, Science in China, B Chem., 47 (2004) 257.

[72] H.C. Choi, Y.M. Jung, I. Noda, S.B. Kim, J. Phys. Chem., B 107 (2003) 5806.

[73] P.J. Tandler, P. de B. Harrington, H. Richardson, Anal. Chim. Acta, 368 (1998) 45. 
[74] Y.M. Jung, H.S. Shin, S.B. Kim, I. Noda, Appl. Spectrosc., 56 (2002) 1562.

[75] R. Dluhy, S. Shanmukh, S.-I. Morita, Surf. Interface Anal., 38 (2006) 1481.

[76] D.L. Elmore, R.A. Dluhy, Colloids and Surfaces, A171 (2000) 225.

[77] K. G. Owens, Applied Spectroscopy. Rev., 27 (1992) 1.

[78] J. Yang, X. Chen, R. Fu, Y. Li, W.-A. Luo, M. Zhang, Polymer Testing, 28 (2009) 456.

[79] J.-F. Boily, E.S. Ilton, Surface Science, 602 (2008) 3637.

[80] J. Rodriguez-Carvajal, Physica B., 192 (1993) 55.

[81] T. Nakamura; K. Sakumoto, M. Okamoto, S. Seki, Y. Kobayashi, T. Takeuchi, M. Tabushi, Y. Yamada, J. Power Sources, 174 (2007) 435.

[82] W. Kündig, H. Bömmel, G. Constabaris, R.H. Lindquist, Phys. Rev., 142 (1966) 327.

[83] Y.-H. Rho, L.F. Nazar, L. Perry, D. Ryan, J. Electrochem. Soc., 154 (2007) A283. 